\title{
強磁性酸化物薄膜における磁界誘導電気分極の直流バイアス電圧依存性
}

\section{Bias Voltage Dependence of Magnetic-Field-Induced Electric Polarization in Ferromagnetic Oxide Films}

\author{
加島 篤・大橋敏弘・井上光輝, ${ }^{*, * k} \cdot$ 藤井壽崇, \\ 北九州工業高等専門学校, 福岡県北九州市小倉南区志井 5-20-1（广802-0985） \\ *豊橋技術科学大学, 愛知県豊橋市天伯町雲雀ヶ丘 1-1（广441-8580） \\ *CREST，科学技術振興事業団，埼玉県川口市本町 4-1-8（广332-0012） \\ *愛知工科大学, 愛知県蒲郡市西迫馬乗 50-2（广443-0047）
}

\author{
A. Kajima, T. Ohashi, M. Inoue ${ }^{*, * k}$, and T. Fujï ${ }^{* * * *}$ \\ Kitakyushu National College of Technology, 5-20-1 Shï, Kokura-minami-ku, Kitakyushu, Fukuoka, 802-0985 \\ "Toyohashi University of Technology, 1-1 Hibarigaoka, Tempaku-cho, Toyohashi, Aichi 441-8580 \\ ${ }^{*}$ CREST, JST, 4-1-8 Honcho, Kawaguchi, Saitama 332-0012 \\ *Aichi University of Technology, 50-2 Manori, Nishihazama-cho, Gamagori, Aichi 443-0047
}

In the past several years, we have reported that electric susceptibility $\chi$ ' is subject to change with external magnetic field $H$ in ferromagnetic nano-composite oxide sputtered films with a $\mathrm{Bi}_{2} \mathrm{O}_{3}-\mathrm{Fe}_{2} \mathrm{O}_{3}-\mathrm{PbTiO}_{3}$ ternary system. The charge displacement current assisted by $H$ and the electric polarization induced by applying a small ac magnetic field, $\Delta P_{\mathrm{h}}(\omega)$, were measured to confirm whether the susceptibility change with magnetic field, $\Delta \chi^{\prime}(H)$, is intrinsic.

In the present study, we found that the detected $\Delta P_{\mathrm{h}}(\omega)$ signal changes depending on both the direction of the magnetic field and the dc bias voltage applied perpendicular to the film plane. To explain these experimental results, we made some alterations to the previous model based on magnetization rotation. From capacitance vs. voltage measurement, it was found that, since we used Si-wafers as substrates, a depletion layer attributed to the MIS structure is formed in the film-to-Si interface. This effect could ultimately be eliminated by applying a forward-biased electric field.

Key words: EM-effect, ferromagnetic oxide films, electric susceptibility, nano-composites, reactive rf-sputtering

\section{1. はじめに}

我々は，高周波反応性スパッタ法で作製した $\mathrm{Bi}_{2} \mathrm{O}_{3}-\mathrm{Fe}_{2} \mathrm{O}_{3}$ $\mathrm{PbTiO}_{3}$ 系磁性酸化物薄膜を用いた薄膜コンデンサにおいて, 直流 磁界の印加によって膜の帯電率が室温で最大 $1 \%$ 程度変化するこ とを見い出した 1,2$)$. 新型の電気磁気効果と考えられるこの現象は $1 \mathrm{~Hz}$ から $1 \mathrm{MHz}$ の広い周波数範囲で観察された. ここで磁界によ る帯電率変化 $\Delta \chi^{\prime}(H)$ はヒステリシスを示し保磁力 $H_{\mathrm{C}}$ で極小となる など，磁化特性と密接に関係した現象であることが分かった。ま た，現象論的モデルを用いて試料の磁化曲線から帯電率変化を求 めた理論曲線で, 測定結果が非常によく再現できることが分かっ た3,4).

次に, 帯電率変化が見かけの現象では無いことを示すために, 磁界印加時の変位電流を測定し, 膜表面に誘起される電荷量が磁 界の大きさに依存して変化し，帯電率変化と類似の特性を示寸こ とを確認した．更に，交流磁界印加による薄膜コンデンサの誘起 電圧を測定して，磁界によって電気分極が誘導されることを確か めた．その結果，磁界による帯電率や電荷量の変化は，一種の電 気磁気効果 $\left[(\mathrm{EM})_{\mathrm{H}^{-} \text {効果 }}\right.$ による磁界誘導電気分極に起因寸る現象
であることが分かった5）。

これら薄膜の結晶構造は，XRDや電子線回折法を用いた過去の 研究において, 熱処理の後もアモルファス状態を保っていること が分かっている6)。しかしながら数kOeに及ぶ高い保磁力と $10^{7}$ $\Omega \mathrm{m}$ 高い電気抵抗から, 実際はglass-network状の誘電性母体中 に回折法では検出できない微細な強磁性クラスタが分散したナ ノ・コンポジット構造をとっていると推察される. しかし, この ような系で磁界誘導電気分極が発現するメカニズムについてはま だ明らかにされておらず，その発現機構解明には詳細な電気分極 特性の測定が不可欠である.

そこで今回は, 先ず直流磁界や微小交流磁界の印加方向を変え て誘導される電気分極を測定した．また，膜に直流バイアス電圧 を加えた状態で磁界誘導電気分極を測定し, 直流電界によって大 きな変化が生じることを見出した. そしてこれら実験結果が，誘 電性母体中に分散した強磁性ナノ・クラスタの磁化回転に伴う磁 歪・圧電効果を考慮したモデル5)を一部修正することで, 定性的に 説明できることが分かった．また下地基板にSiを用いていること によって生じるMIS構造が電気分極に及ぼす影響についても考察 を行った.

\section{2. 実験方法}

薄膜試料は，高周波プレーナー・マグネトロン型スパッタリン グ装置を用い，高純度試薬を調合した粉末ターゲットを $\mathrm{Ar}, \mathrm{O}_{2}$ 雰井気中で反応性スパッタして作製した．基板には $\rho=0.80 \sim 1.20$ $\Omega \mathrm{cm}$ の低抵抗 $\mathrm{n}$ 型 $\mathrm{Si}$ ウエハーを用いた. スパッタ時の基板温度 は $150^{\circ} \mathrm{C}$ 保ち, 約 $1 \mu \mathrm{m}$ 厚に成膜した. 膜組成は, 大気中熱処理 によって大きな磁化を発現する $0.18 \mathrm{Bi}_{2} \mathrm{O}_{3}-0.70 \mathrm{Fe}_{2} \mathrm{O}_{3}-0.12$ $\mathrm{PbTiO}_{3}$ に固定した. また後熱処理は最大磁化になる $600^{\circ} \mathrm{C}$ 一定で 3 時間行った. 続いて薄膜上部に $\mathrm{Al}$ 電極を蒸着し, 下部電極であ る $\mathrm{Si}$ 基板からの ohmic contact を確保するため, 粗く研磨した $\mathrm{Si}$ 基板裏面に In を蒸着して平行平板型薄膜コンデンサを形成した.

交流変調法を用いた磁界誘導電気分極の測定システムを Fig. 1 に示す. 試料の薄膜コンデンサは, 厚さ $0.1 \mathrm{~mm}$ の銅䈃製シールド ケースに納められ電磁石の空隙中にセットされる. 装置の制約か ら, 印加する直流磁界は最大 $4.5 \mathrm{kOe}$ である. また, 直流磁界と 


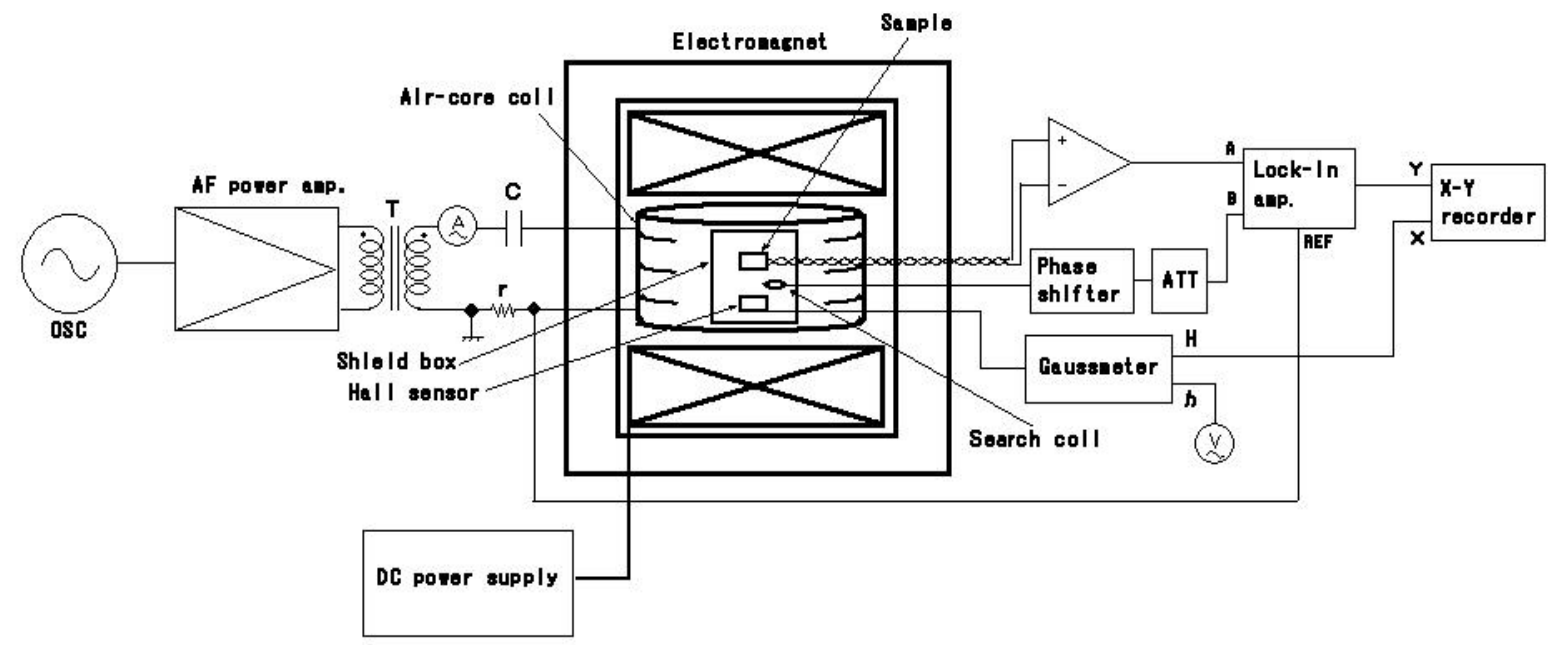

Fig. 1 Circuit diagram for measuring electric polarization induced by applying an ac magnetic field.

同軸に配置した空心のソレノイドコイルによって $102.5 \mathrm{~Hz}$ ，最大 值 75 Oe の低周波交流磁界を重畳させ，電気分極の誘導によって 生じた微少交流電圧を検出する. バックグラウンド・ノイズを除 去するためツイストペア線を用い，探りコイルの誘起電圧との差 動をとって信号電圧だけをロックインアンプに入力する. 交直両 方の磁界はホール素子で同時に計測し，直流磁界を横軸に誘導電 気分極によって生じた信号電圧を縦軸にして X-Y レコーダで記録 した.

また, 磁界誘導電気分極に対する直流電界の影響を調べるために, 差動増幅器の入力部に乾電池を電源とする直流バイアス電圧 $に の$ 付加回路を設置して, ツイストペア線を通してシールドボックス 内の試料ににを印加した。

\section{3. 実験結果と考察}

\section{1 磁界誘導電気分極の磁界印加方向による変化}

以前報告した磁界による帯電率変化 $\Delta \chi^{\prime}(H)$ の測定では，直流磁 界Hの印加方向を膜面に平行または垂直のいずれにとっても, 電極 間 (膜厚方向) で計測した $\Delta \chi^{\prime}(H)$ の大きさやヒステリシス曲線の 形状に変化は見られなかった1），そこで, 磁界誘導電気分極につい ても, 磁界印加方向による変化の有無を調べた. この測定では, 微小交流磁界 $\tilde{h}(\omega)$ を直流磁界 $H$ と同一方向に重畳して試料の薄膜 コンデンサに印加し, 分極の変化は膜厚方向に発生する交流電圧 として検出している.

Fig. 2 に示すように, 磁界印加方向が膜面に垂直な場合は, 誘 導された電気分極 $\Delta P_{\mathrm{h}}(\omega)$ はヒステリシスを伴う変化が観察される のに対し, 膜面内に磁界を印加した場合は信号が全く検出されな かった.この結果は, 磁界印加方向と信号検出方向が平行な場合 にのみ $\Delta P_{\mathrm{h}}(\omega)$ 信号が得られることを示している.

\section{2 磁界誘導電気分極の直流バイアス電圧依存性}

次の段階として, 直流磁界 $H$ と微小交流磁界 $\tilde{h}(\omega)$ を加えた状態
で，直流電界 $E$ を膜厚方向に印加した場合の $\Delta P_{\mathrm{h}}(\omega)$ の変化を調べ た. 膜面に垂直に磁界を印加した場合の測定結果をFig. 3 に示す. ここでりは薄膜コンデンサに印加する直流バイアス電圧で, $\mathrm{Si}$ 基 板を+にする極性を 極へ向かっている. また, $H$ も Si基板からAl電極へ向から方向を正 としている.

$V_{b}=0$ (Fig. 2(a)の曲線に相当) から 石を負に変化させていくと， $H<0$ では $\Delta P_{\mathrm{h}}(\omega)$ 信号に大きな変化は見られないが， $H>0$ では $\Delta P_{\mathrm{h}}(\omega)$ が徐々に増加し $V_{\mathrm{b}}=-0.8 \mathrm{~V}$ でほぼ左右対称な曲線になる. 一方， V砛正の場合はHの極性によって曲線の形状が大きく異な り, $V_{b}=+0.8 \mathrm{~V}$ では $\Delta P_{\mathrm{h}}(\omega)$ が $H<0$ で増大し $H>0$ で下に凸の曲 線となるなど複雑な変化を示している.

なおFig. 2(b) と同様に磁界を膜面内に印加した場合は, V石を変化 させても $\Delta P_{\mathrm{h}}(\omega)$ 信号は検出されなかった.

\section{3 磁化回転モデルによる考察}

これまで論文で展開してきた磁化回転モデルを一部修正するこ とで，本報を含め全ての実験結果を説明することができることを

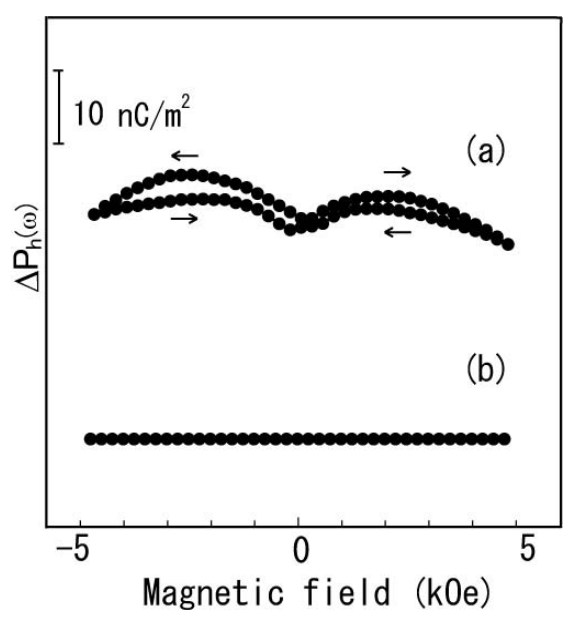


(a) perpendicular and (b) parallel to the film plane. 


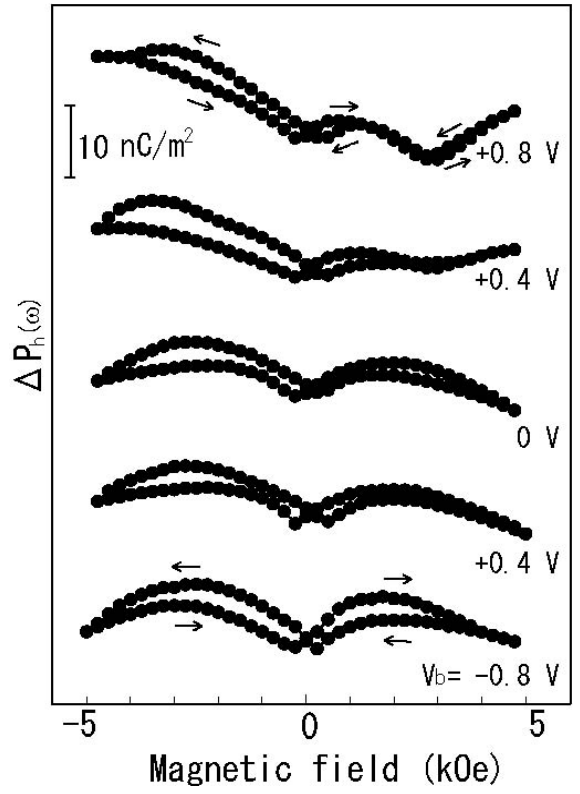

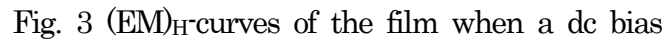
voltage $V_{b}$ was applied perpendicular to the film plane.

示す. 先ずモデルの概要を記す.

膜構造は強磁生酸化物ナノ・クラスタがガラス様誘電性母体中に 無秩序に分散しているものとする. クラスタは単磁区で同一の飽 和磁化 $M_{\mathrm{S}}$ をもち, 磁化過程は磁化回転によって生じるものと仮定 する. 更に磁界Hの下での磁化回転角はクラスタ毎に異なっている が，試料全体の平均ではFig.4 に示すように頂角 $\theta$ の円錐面上に傘 を開くように一様に分布するものとする. したがって

$$
\cos \theta=M(H) / M_{\mathrm{s}},
$$

の関係がある．また，クラスタ間の磁気双極子相互作用や磁歪に よるクラスタの形状変化によって, クラスタ周辺の誘電性母体 glass-networkが変形を受け，電気分極を発現させるイオン変位を 助長させるものとする. この効果が $\{M(H)\}^{2}$ に比例すると仮定す ると，Hによって誘導される帯電率変化 $\Delta \chi^{\prime}(H)$ は,

$$
\Delta \chi^{\prime}(H)=\left|\Delta \chi^{\prime}(H)\right|_{\max }\left(\frac{M(H)}{M_{\mathrm{s}}}\right)^{2},
$$

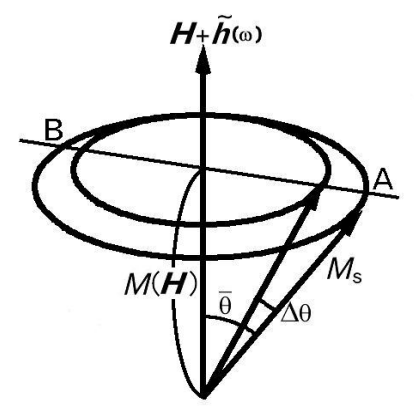

Fig. 4 Simplified model of magnetization rotation.
となる，実際，式(1)で実験結果を極めてよく再現できることが分 っている2,3)

次に, $H$ に微小交流磁界 $\tilde{h}(\omega)=\Delta h e^{j \omega t}$ を同じ方向 $(\mathrm{z}$-軸)に重 畳させた場合は,

$$
\begin{aligned}
& \Delta \chi^{\prime}(H+\tilde{h}(\omega))=\left|\Delta \chi^{\prime}(H)\right|_{\max }\left(\frac{M(H+\tilde{h}(\omega))}{M_{\mathrm{s}}}\right)^{2} \\
& \approx\left|\Delta \chi^{\prime}(H)\right|_{\max }\left\{\left(\frac{M(H)}{M_{\mathrm{s}}}\right)^{2}+\frac{d}{d H}\left(\frac{M(H)}{M_{\mathrm{s}}}\right)^{2} \tilde{h}(\omega)\right\},
\end{aligned}
$$

と書ける．上式中，右辺第 1 項は式(2)であり，第 2 項は

$$
\Delta \chi^{(i j)}(\tilde{h}(\omega))=\frac{d}{d H}\left(\frac{M(H)}{M_{\mathrm{s}}}\right)^{2} \tilde{h}(\omega) t_{i j}
$$

であり, $\tilde{h}(\omega)$ による帯電率変化テンソルを表す.ただし，式(4)中 の $\boldsymbol{t}_{i j}$ は, 直流電界 $E$ の下で検出される電気分極が $h(\omega)$ と平行なとき に限られるといら実験条件から導入したもので, $t_{z z}=1, t_{i j}=0$ (その他の $i j)$ である[付録参照. これから，交流電界e $(\omega)$ で誘導さ れる一次の交流電気分極变化 $\Delta P_{\mathrm{e}}^{(i)}(\omega)$ は, 式(5)で与えられる.

$$
\begin{aligned}
\Delta P_{\mathrm{e}}^{(i)}(\omega) & =\Delta \chi^{\prime}(H) \tilde{e}_{i}(\omega) \\
& =\left|\Delta \chi^{\prime}(H)\right|_{\max }\left(\frac{M(H)}{M_{\mathrm{s}}}\right)^{2} \tilde{e}_{i}(\omega), i=x, y, z
\end{aligned}
$$

また, 直流電界ED下, 微小交流磁界 $\tilde{h}(\omega)$ で誘導される一次の交流 電気分極変化 $\Delta P_{\mathrm{E}}^{(i)}(\omega)$ は式 $(6 \mathrm{a}, 6 \mathrm{~b})$ で与えられる.

$$
\begin{aligned}
\Delta P_{\mathrm{E}}{ }^{(z)}(\omega) & =\Delta \chi^{(z z)}(\tilde{h}(\omega)) E_{z} \\
& =\left|\Delta \chi^{\prime}(H)\right|_{\max } \frac{d}{d H}\left(\frac{M(H)}{M_{\mathrm{s}}}\right)^{2} \tilde{h}(\omega) E_{z}, \quad(6 \mathrm{a})
\end{aligned}
$$

および

$$
\Delta P_{\mathrm{E}}^{(x)}(\omega)=\Delta P_{\mathrm{E}}^{(y)}(\omega)=0
$$

となる.

これに加えて, 電界を印加しなくても $\tilde{h}(\omega)$ の印加だけで電気分 極変化を生じる.これは一種の電気磁気効果 $\left[(\mathrm{EM})_{\mathrm{H}}\right.$-効果 $]$ といえ るものである，この理由は付録で述べるが，次式で与えられる.

$$
\begin{aligned}
& \Delta P_{\mathrm{h}}^{(z)}(\omega)=\Delta \alpha(H) \tilde{h}(\omega) \\
&=\zeta\left|\Delta \chi^{\prime}(H)\right|_{\max } \frac{d}{d H}\left(\frac{M(H)}{M_{S}}\right)^{3} \tilde{h}(\omega)
\end{aligned}
$$




$$
\Delta P_{\mathrm{h}}^{(x)}(\omega)=\Delta P_{\mathrm{h}}^{(y)}(\omega)=0 .
$$

ただし，式(7a)中の $\Delta \alpha(H)$ は, 電気磁気感受率に対応する係数であ り, らは誘電性母体の圧電定数に関係する定数である. ところで $E$

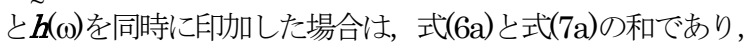

$\Delta P_{\mathrm{h}}(\omega)=\zeta\left|\Delta \chi^{\prime}(H)\right|_{\max } \frac{d}{d H}\left[\left(\frac{M(H)}{M_{\mathrm{s}}}\right)^{3}+\eta E\left(\frac{M(H)}{M_{\mathrm{s}}}\right)^{2}\right] \tilde{h}(\omega)$,

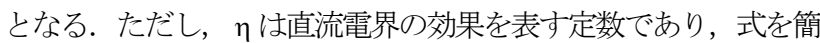
潔にするため添字 $\mathrm{z}$ を省略した.

さて，実験では電界の印加および電気分極の信号検出は試料膜 厚方向であるが，磁界印加方向は任意である. 今回の実験ではFig. 5 に示寸ように磁界を膜面垂直方向（図(a)）と膜面内(図(b))に印

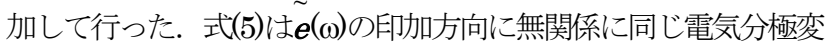
化が得られることを意味し，既に論文(1)で示した実験結果と一致

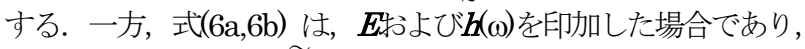

Fig. 5(a)のようにEが $\boldsymbol{h}(\omega)$ に平行なときだけ電気分極变化が観測 されることを示しており, 本報の実験結果の重要な結論と一致し ている. また，式 $(7 \mathrm{a}, 7 \mathrm{~b})$ も電気分極変化が観測されるのは $\tilde{h}(\omega)$ に 平行な成分に限られ，Fig. 2 の実験結果と定性的に一致する.

次に, Fig.3の実験を式(8)の理論と比較した結果をFig.6に示す. 先ず, 直流電圧を印加していない $\eta E=0$ の場合の $\Delta P_{\mathrm{h}}(\omega)$ を Fig. 2(a)の測定結果と比較すると, Hの極性に関係なく左右対称なヒス テリシスを描き，近似が悪くなる $|H| \leqq H_{\mathrm{C}}$ の領域を除いて曲線の 形状や描く方向は定性的に一致している。 また直流電界を印加し た場合は, $\eta E$ を負に変化するにしたがって $\Delta P_{\mathrm{h}}(\omega)$ 信号の磁界に対 する対称性が失われ， $\eta E=-1.5$ では $H>0$ の領域で曲線が反転 するなど, Fig. 3 の結果と定性的に一致している. このようにHに


0 の領域で得られており, ED効果を表す係数りは負の值をもつ(磁 歪機構では負磁歪）と考えられる.

今回計算に用いた現象論的モデルでは，(EM) $\mathrm{H}^{-}$効果の発現機構 として強磁性クラスタの磁歪と誘電性母体の圧電効果を仮定した. しかし，基板に拘束された薄膜試料という困難さもあって，磁歪
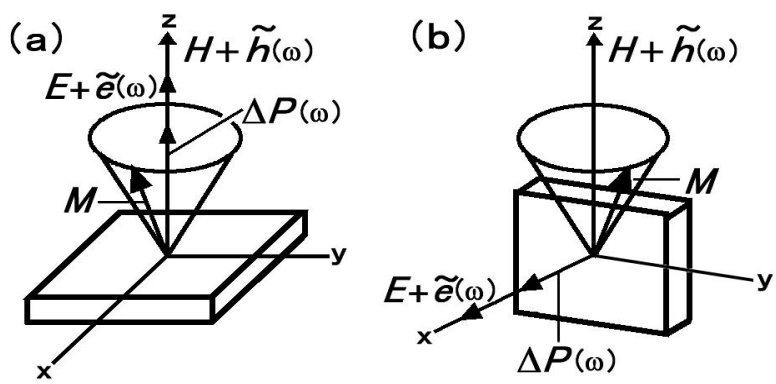

Fig. 5 Geometric configuration of $(\mathrm{EM})_{\mathrm{H}^{-} \text {signal }}$ detection.
(a) Detection // H+ $h(\omega)$
(b) Detection $\perp H+\tilde{h}(\omega)$

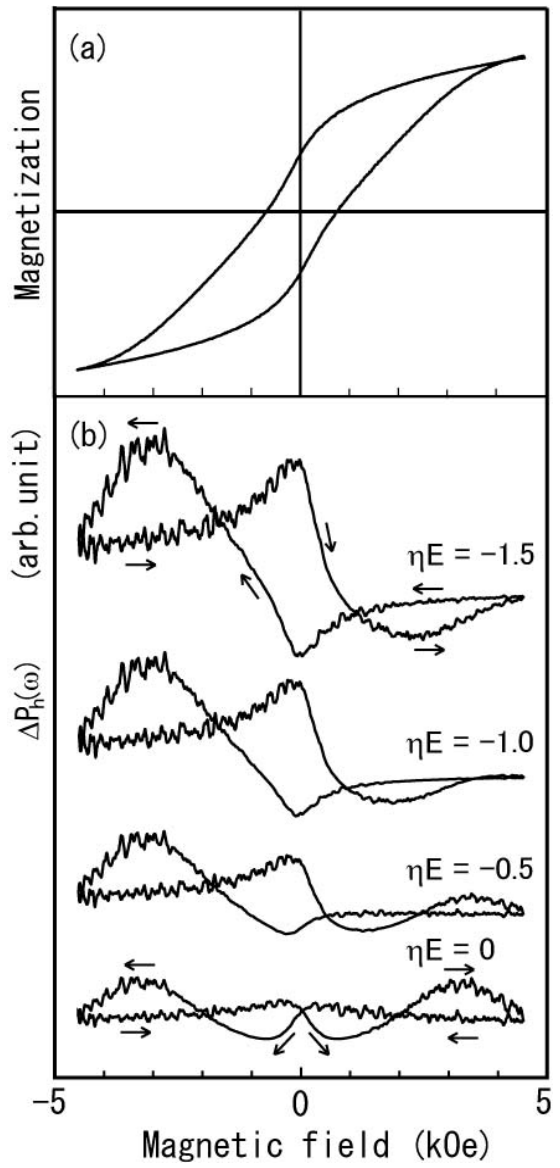

Fig. 6 (a) Magnetization curve [experiment], (b)

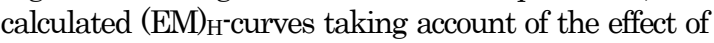
E.

や圧電効果の実験的検証はできていない. 磁界誘導電気分極の微 視的な発現機構を明らかにすることは, 今後の重要な研究課題で ある.

\section{4 MIS 構造の形成とその影響}

直流バイアス電圧の効果を更に詳しく検討すると, 磁化回転モ デルを用いて計算したFig. 6(b)の $E=0$ に対応する左右対称な曲 線は, Fig. 3 の実験結果では $V_{b}=-0.8 \mathrm{~V}$ で現れている.これは 0 の状態で膜中に $E>0$ の直流電界が存在する可能性を示唆して いる. 試料の薄膜コンデンサは，下部電極であるSi基板上に絶縁 性の磁性膜とAl電極を積層しており一種のMIS構造となっている. したがって, $\quad \zeta=0$ の熱的平衡状態で, $\mathrm{Al}$ n型Siの仕事関数の差 や磁性膜中の空間電荷などが原因となって, 磁性膜とSi表面のバ ンドが傾斜・湾曲して電界が生じていると考えられる.

これを確認するため，3つの周波数における試料の $\mathrm{C}-\mathrm{V}$ 特性を 測定した結果をFig. 7 に示す.これはMIS構造特有の特性を示して いる7）。㫐=0でSiの表面付近に空乏層が生じており，磁生膜の 静電容量 $C_{0}$ に空乏層容量 $C_{\mathrm{d}}$ が直列に入るため薄膜コンデンサ全 体の静電容量 $C$ は, $1 / C=1 / C_{0}+1 / C_{\mathrm{d}}$ となって磁性膜本来の值

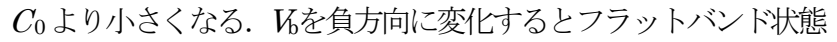
となって空乏層が消滅し, $-2 \mathrm{~V}$ 以下では蓄積状態となって $C=C_{0}$ 


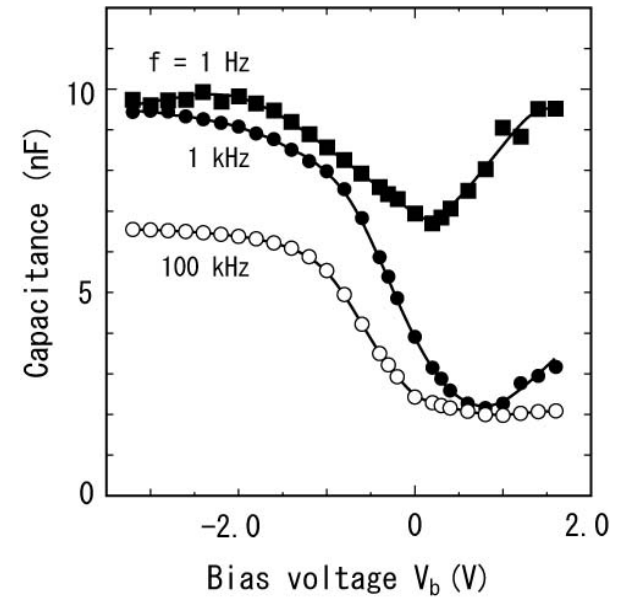

Fig. 7 Capacitance-voltage characteristics of the film.

まで上昇する. 一方 転層の形成によっての上昇が夕られるが, 周波数が上昇寸ると反 転層は形成されず空乏層が拡大して $C$ 低下した值に留まってい る. このようにMIS構造の形成によってバイアス電圧 $に$ と実際に 磁性膜にかかる電圧との間に差が生じることが確認された. その 一方で, 磁界誘導電気分極による $C_{0}$ の電荷変化はそのまま $C$ の両 端に現れ電圧として検出されるため, $\Delta P_{\mathrm{h}}(\omega)$ 信号自体は空乏層容 量の影響を受けないと考えられる.

しかし，交流電界で励振する帯電率変化 $\Delta \chi^{\prime}(H)$ の測定では，空 乏層容量によって磁性膜にかかる交流電圧も減少寸るため，見か けの $\Delta \chi^{\prime}(H)$ が低下寸ることが予測される. これを確認するために, キャパシタンスブリッジ 1)の交流電圧源に直流バイアス電圧を重 畳して $\Delta \chi^{\prime}(H)$ を 測定した. Fig. 8 に示すように $\Delta \chi^{\prime}(H)$ 曲線はバイ アス電圧りによって変化し, 各周波数における帯電率変化の大き さ $\left|\Delta \chi^{\prime}(H)\right|_{\max }$ は空乏層が拡大寸る場合に低下し，Fig. 7 のC-V特 性を忠実に反映している. よって，MIS構造に伴う空乏層容量が $\Delta \chi^{\prime}(H)$ の 測定結果に影響を与えていることが確認された.

MIS 構造の形成は本研究の目的から好ましいものではない. MIS 構造のない 薄膜コンデンサを実現するため, 下部電極として

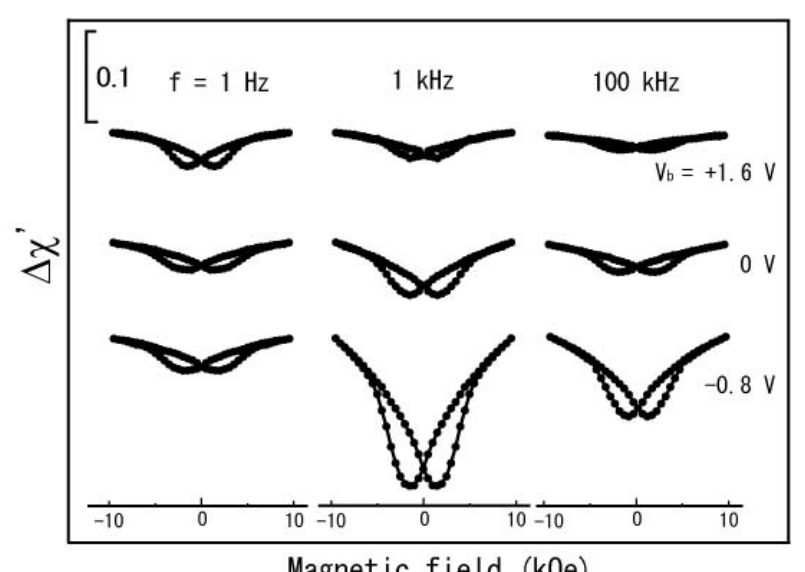

Fig. 8 Bias voltage dependence of $\Delta \chi^{\prime}(H)$ for three different frequencies.
不純物濃度の高い超低抵抗率の $\mathrm{Si}$ 基板や導電性酸化物薄膜を使つ た実験を進めている. これによって正確な $\Delta \chi^{\prime}(H)$ の值が求められ て，高周波における特性も改善できると考えられる.

\section{4. まとめ}

$\mathrm{Bi}_{2} \mathrm{O}_{3}-\mathrm{Fe}_{2} \mathrm{O}_{3}-\mathrm{PbTiO}_{3}$ 三元系スパッタ薄膜において磁界によっ てアシストされた電気感受率の変化が観測され, 一種の電気磁気 効果 $\left[(\mathrm{EM})_{\mathrm{H}}\right.$-効果 $]$ と考えられる. 本研究ではその発現機構の解明 に繋げることを目的に, 微少交流磁界で誘導された電気分極 $\Delta P_{\mathrm{h}}(H)$ の磁界印加方向による変化やその直流バイアス電圧依存 性を測定した.

その結果, $\Delta P_{\mathrm{h}}(H)$ は磁界印加と信号検出の方向が平行な場合に の夕検出されることが分かった. また直流バイアス電圧の印加に よって $\Delta P_{\mathrm{h}}(\omega)$ のヒステリシス曲線の形状が大きく変化することを 見出した. これらの現象は強磁性クラスタの磁化回転と形状変化 を考慮したモデルによって統一的に説明できることが分かった.

更に, 直流バイアス電圧依存性における実験とモデルによる計 算結果の比較から, Si を下地基板に用いた薄膜コンデンサでは薄 膜一基板インターフェースに MIS 構造が形成され, そのため空乏 層容量が磁界による帯電率変化の測定值に影響を与えていること が確認された.

\section{付 録}

\section{式(4)および式(7a)の導出}

直流磁界 $H$ および微小交流磁界 $\boldsymbol{h}(\omega)$ は $\mathrm{z}$-方向に印加し, 一方直流 電界 $\boldsymbol{E}$ 秥よひ微小交流電界 $\tilde{e}(\omega)$ は任意方向に印加するものとする. すなわち,

$$
\begin{array}{cc}
H=\left[\begin{array}{c}
0 \\
0 \\
H
\end{array}\right], & \tilde{h}(\omega)=\left[\begin{array}{c}
0 \\
0 \\
\tilde{h}(\omega)
\end{array}\right] \\
\boldsymbol{E}=\left[\begin{array}{c}
E_{X} \\
E_{y} \\
E_{z}
\end{array}\right], & \tilde{e}(\omega)=\left[\begin{array}{c}
\tilde{e_{\mathrm{x}}}(\omega) \\
\tilde{e} \\
\tilde{e}_{\mathrm{y}}(\omega) \\
\tilde{e_{\mathrm{z}}}(\omega)
\end{array}\right] .
\end{array}
$$

$H$ assistの下, 誘導される電気分極の $\tilde{h}(\omega)$ および $(\omega)$ による一次の 変化は，以下の三つの寄与からなる.

$$
\begin{aligned}
\Delta P(\omega) & =\Delta P_{\mathrm{e}}(\omega)+\Delta P_{\mathrm{E}}(\omega)+\Delta P_{\mathrm{h}}(\omega) \\
& =\Delta \chi^{\prime}(H) \tilde{e}(\omega)+\Delta \chi^{(i j)}(\tilde{h}(\omega)) E+\Delta \alpha(H) \tilde{h}(\omega) .
\end{aligned}
$$

それぞれの項は本文の式(5), 式(6)および式(7)に対応する.ここで 式(4)〜式(7)の導出について説明する. $\mathrm{z}$-軸方向に印加した磁界 $H$ 
$+\tilde{h}(\omega)$ の 下での磁化状態はFig. 4 であるが, 角度 $\theta$ の円錐の一断面

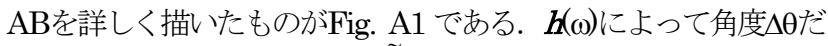
け変化を受けるが, 磁化変化 $\Delta \tilde{m}(\omega)$ を磁界に平行な成分と垂直な 成分にわけると，

$$
\begin{aligned}
\tilde{\Delta m_{/ /}(\omega)} & =\tilde{\Delta}(\omega) \sin \theta=M_{\mathrm{s}} \Delta \theta \sin \bar{\theta} \\
& =M_{\mathrm{s}} \frac{d}{d H}\left(\frac{M(H)}{M_{\mathrm{s}}}\right) \tilde{h}(\omega),
\end{aligned}
$$

および

$$
\Delta \tilde{m}_{\perp}(\omega)=\Delta \tilde{m}(\omega) \cos \theta=M_{\mathrm{s}} \Delta \theta \cos \bar{\theta}=M(H) \Delta \theta
$$

となる. ところが, 図の点Aと点Bでは, 前者は同相で変化するが, 後者は逆相で変化するので互いに相殺される. 寸なわち, 印加し た電界の中信号として検出されるのは磁界に平行な成分( $\mathrm{z}$-成分) に限られる. 式(4)で $t_{Z Z}=1, t_{i j}=0$ (その他の $\left.i j\right)$ は，この事情を 表すためである.


ノ・クラスタが磁歪をもち，その形状変化を通して帯電率変化を 生じるものと考える. この事情を説明するため, Fig. A2 に示すよ うにクラスタ集合体の形状は，磁化がランダムな方向を向いた消 磁状態 $M(H)=0$ で球形とし, 磁界印加によって磁化回転が生じる とH方に伸びて回転棈円体に変形寸るものとする (図は磁気飽和 前の状態を表しており, 正磁歪として $\boldsymbol{H}$ 方向に伸びているように描 いてある)。ここで $\theta$ 方向の磁化ベクトル $M$ を持つクラスタに注目 すると, クラスタ集合体全体の変形におけるこのクラスタの伸び の寄与はラジアル方向で $\delta \propto \cos ^{2} \theta$ となり ${ }^{8)}$, その磁界 $\boldsymbol{H}$ に平行な成 分 $\delta_{/ /}$

$$
\delta_{/ /}=\delta \cos \theta \propto\left(\frac{M(H)}{M_{\mathrm{S}}}\right)^{3},
$$

で表される. したがって $\tilde{h}(\omega)$ による磁化変化 $\Delta \tilde{m} /(\omega)$ に対応する磁 界方向の微小変位は,

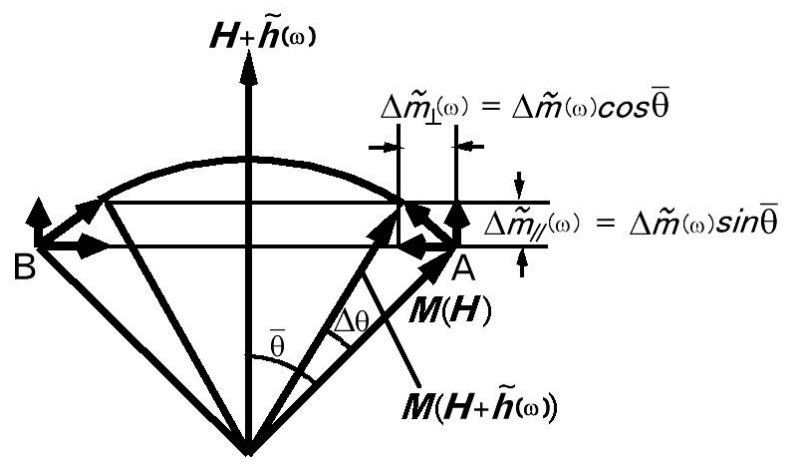

Fig. A1 Change in magnetization with an ac magnetic field.

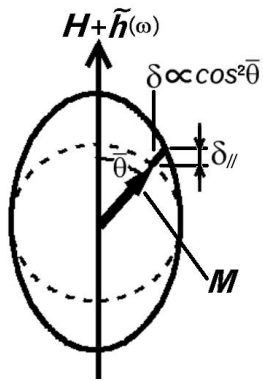

Fig. A2 Elongation of the ferromagnetic cluster assembly caused by magnetostriction.

$$
\begin{aligned}
\Delta \delta_{/ /} & =\frac{d \delta_{/ /}}{d M} \Delta \tilde{m}_{/ /}(\omega) \propto 3\left(\frac{M(H)}{M_{\mathrm{S}}}\right)^{2} \frac{d}{d H}\left(\frac{M(H)}{M_{\mathrm{S}}}\right) \tilde{h}(\omega) \\
& =\frac{d}{d H}\left(\frac{M(H)}{M_{\mathrm{s}}}\right)^{3} \tilde{h}(\omega),
\end{aligned}
$$

に比例する. この歪みがクラスタ周辺の誘電体glass-networkを歪 ませ，発生した応力による圧電効果によって電気分極を発生する ものとする. したがって誘電性母体の圧電定数に比例した定数とを 乗じて式(7)を得る. また, Fig. A1のように $\tilde{m}_{\perp}(\omega)$ は相殺される ため, 磁界に垂直な方向に磁歪による微小変位は生じず電気分極 変化の信号も検出されない.

謝辞 本研究において実験を遂行して下さった学生諸君, 本校専 攻科生産工学専攻平成 14 年度卒の中山 亮氏 (現・豊橋技術科学 大学大学院), 電気工学科平成 14 年度卒の安部英二 (現・(株)ソ 二一宮），石松弘光氏（現・(株)日鉄エレックス），梅田公資氏 (現・(株)ソニーセミコンダクタ）と中野玩也氏（現・(株)レンゴ 一), 並びに電気工学科 5 年生の塩塚充史氏, 田上英人氏, 田村 唯歩季氏, 徳一隆晃氏に感謝致します. 本研究の一部は, 平成 14 年度文部省科学研究費基盤研究(C)および大幸財団学術研究助成の 援助を受けて行ったものである.

\section{References}

1) A. Kajima, Y. Nakamura, M. Inoue and T. Fujii: J.Magn.Soc.Jpn., 25,875 (2001).

2) T. Fujii, A. Kajima and M. Inoue: Proc. Internat. Conf. on Composites Engng., (2001) Tenerife,Spain.

3) A. Kajima, R. Nakayama, M. Inoue and T. Fujii: J.Magn.Soc.Jpn., 26,445(2002).

4) A. Kajima, R. Nakayama, T. Fujii and M. Inoue: J.Magn.Magn. Mater., 258-259,597 (2003).

5) A. Kajima, R. Nakayama, ,T. Ohashi, M. Inoue and T. Fuji: J.Magn.Soc.Jpn., 27,348 (2003).

6) A. Kajima, T. Kaneda, H. Ito, T. Fujii and I. Okamoto: J.Appl..Phys.,70, 3760 (1991).

7) A. S. Grove: Physics and Technology of Semiconductor Devices, p.275 (John Wiley \& Sons, New York, 1967)

8) S.Chikazumi: Physics of Ferromagnetism, Vol.2, p.107 (Shokabo, Tokyo, 1984)

\section{4 年 3 月 23 日受理, 2004 年 7 月 20 日採録}

